\title{
Study on influence of the PTA-P welding process parameters on corrosion behavior of Inconel 625 coatings
}

\author{
Aureliano Xavier dos Santos ${ }^{1}$, Theophilo Moura Maciel ${ }^{1}$, Josiane Dantas Costa ${ }^{2}$, \\ Mikarla Baía de Sousa ${ }^{2}$, Shiva Prasad ${ }^{3}$, Ana Regina Nascimento Campos ${ }^{3}$, \\ Renato Alexandre Costa de Santana ${ }^{3}$
}

\footnotetext{
${ }^{1}$ Department of Mechanical Engineering, Federal University of Campina Grande, Av. Aprígio Veloso, 882, CEP:58429140, Campina Grande, Paraíba, Brazil.

${ }^{2}$ Department of Chemical Engineering, Federal University of Campina Grande, Av. Aprígio Veloso, 882, CEP: 58429140, Campina Grande, Paraíba, Brazil.

${ }^{3}$ Department of Biology and Chemistry, Federal University of Campina Grande, R. Olho da Água da Bica, S. N., CEP: 58175-000, Cuité, Paraíba, Brazil.

e-mail: aurelliano@yahoo.com.br, theophilo.maciel@ufcg.edu.br, josianeeq@gmail.com, mikarlabaia@ hotmail.com, prasad@deq.ufcg.edu.br, arncampos@yahoo.com.br, renatoacs@ufcg.edu.br
}

\section{ABSTRACT}

In the present work, PTA welding process was used to investigate the influence of welding parameters on the dilution, microhardness and corrosion resistance of Inconel 625 alloy coatings on the API 5L X70 grade steel. The electrochemical impedance spectroscopy (EIS) and linear potentiodynamic polarization (LPP) measurements were used to study the protection properties of the deposited layer when immersed in a $3.5 \%$ $\mathrm{NaCl}$ solution. The results of EIS and LPP have shown that the corrosion resistance results were more satisfactory for coatings with higher dilution index. The results also showed that the dilution values D (\%)varied from $15.33 \%$ to $4.39 \%$ at the maximum $(18.99 \mathrm{~kJ} / \mathrm{cm})$ and the minimum $(8.34 \mathrm{~kJ} / \mathrm{cm})$ welding energy levels. The most relevant dilution value obtained was $4.39 \%$.

Keywords: Plasma transferred arc-welding; coatings; dilution; corrosion.

\section{INTRODUCTION}

The concern with the environment comes motivating several researches on the use of new materials to extend the life of equipment that operates in harsh environments in oil and gas sector. One alternative that has been used is the application of coatings with high corrosion-resistance materials by welding process[1].

Among the materials used for the manufacture of pipes, high-strength and low alloy (HSLA) steels, are the most widely used for this purpose. In Brazil the API 5L X70 grade steels are the most used in the manufacture of pipelines because of the following properties: good combination of, high mechanical strength, with good toughness, ductility and weldability [2-4]. However, these steels are susceptible to corrosion by tension, hydrogen permeation and variation of the $\mathrm{pH}$ of the transported fluids[3,5,6]. To increase the service life of API 5L X70 grade steel and reduction of maintenance costs the surface protection techniques such as: thermal spray metallization, galvanization, electroplating, painting, diffusion, chemical reduction (nickel plating) and weld coating are used [1,7].

Among the various welding processes used for the coatings application of, the Plasma Transferred Arc-Powder (PTA-P) can be highlighted. In this process an constricted electrical arc (plasma) is established between a non-consumable tungsten electrode and the workpiece. The addition material is used in powder form (mixture of powder or atomized alloys), providing a coating of excellent quality.. When compared with other welding processes, PTA-P produces very low dilution measuring from $6 \%$ to $10 \%$ [8], much lower than $20 \%$ to $25 \%$ obtained with other arc welding processes. The low distortion, small heat-affected zone and refined microstructure are also highlights of this technique $[9,10]$.

The PTA-P is used in many applications, when low dilution, reduced heat transfer, high deposition 
rate and ease of operation due to the better process control is necessary as coating application [11].

Between the available coatings alloys, nickel based alloy have gained prominence in recent years due to their great performance under conditions of corrosion, abrasion and high temperature with a relatively low cost [12].

According to AL-FADHLI., et al.[13], Inconel 625 has high corrosion resistance and high ductility that make it a material suitable for surface modification of oil and gas components, especially those made with HSLA steel. Thus, the lifetime of industrial parts is being diluted in severe corrosive media by this method. Inconel 625 is a nickel-based non-magnetic superalloy of Nickel-chromium-molybdenum strengthened mainly by solid solution hardening effect of refractory metals, niobium and molybdenum in a FCC austenitic $\gamma$ matrix.

Given this, the present work is aimed to verify the influence of welding parameters on the dilution, microhardness and corrosion resistance of coating of Inconel 625 superalloy applied by PTA-P process, making use of the factorial design experiment and response surface methodology (RSM).

\section{EXPERIMENTAL PROCEDURE}

\subsection{Material}

The base material used in the study was the API 5L X70 steel used in pipeline manufacturing. Nickel alloy AWS ER NiCrMo-3 (Inconel 625) in atomized powder form with particle size 60 to $63 \mu \mathrm{m}$ was used as filler metal. Argon gas with a purity of $99.99 \%$ was used for the three gas streams (shielding, plasma and drag gas). The chemical composition of the base metal and of the addition metal are presented in Table 1.

Table 1: Chemical composition of API X70 steel and of Inconel 625 alloy.

\begin{tabular}{l|l|l|l|l|l|l|l|l|l|l|l|l|l}
\hline $\begin{array}{l}\text { ELEMENT, } \\
\text { (WT\%) }\end{array}$ & $\mathbf{C}$ & $\mathbf{S i}$ & $\mathbf{M n}$ & $\mathbf{P}$ & $\mathbf{S}$ & $\mathbf{C r}$ & $\mathbf{M o}$ & $\mathbf{N i}$ & $\mathbf{A l}$ & $\mathbf{C u}$ & $\mathbf{T i}$ & $\mathbf{F e}$ & $\begin{array}{l}\mathbf{N b +} \\
\mathbf{T a}\end{array}$ \\
\hline API 5L X70 & 0.19 & 0.24 & 0.7 & 0.018 & 0.018 & 0.064 & 0.008 & 0.07 & - & - & - & - & - \\
\hline $\begin{array}{l}\text { ER NiCrMo } \\
-3\end{array}$ & 0.1 & 0.5 & 0.5 & 0.020 & 0.015 & $\begin{array}{l}20.0- \\
3.0\end{array}$ & $\begin{array}{l}8.0- \\
10.0\end{array}$ & 58 & 0.4 & 0.5 & 0.4 & 3.8 & $\begin{array}{l}3.1- \\
4.15\end{array}$ \\
\hline
\end{tabular}

\subsection{Welding}

The depositions were conducted by the PTA_P welding process an electronic source of welding and data acquisition system for control of parameters was used. The welding parameters varied in the experiments were the current $(\mathrm{A})$, welding speed $(\mathrm{S})$ and powder feed rate $(\mathrm{F})$.

The welding was executed in the flat position, using a $2 \%$ thorium oxide (EWTh-2) tungsten electrode, with $3.1 \mathrm{~mm}$ diameter and $1 \mathrm{~mm}$ indentation. The angle of the tip of the electrode was kept at $30^{\circ}$ for all experiments. The inclination of the welding torch was $90^{\circ}$ to the horizontal), in the "pushing" welding direction. DC current mode with reverse polarity and DBP of $10 \mathrm{~mm}$ were kept constant. An overlap of L/2 relative to the width of the first weld bead was used, as shown in Figure 1, always maintaining the interpass temperature less than or equal to $100^{\circ} \mathrm{C}$.

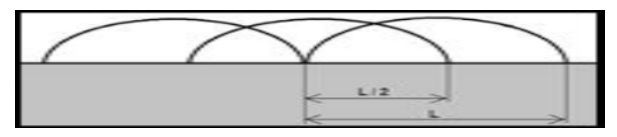

Figure 1: Illustration of the overlap between the weld beads.

\subsection{Factorial Design}

An Experiment Design (DOE) associated to response surface methodology (RSM) was used as an optimization tool. The use of these optimization techniques has increased in recent years in different areas of knowledge[1,14-17]. A complete factorial design of two levels and three factors $\left(2^{3}\right)$ was used, with three replications at the center point and, therefore, a total of 11 experiments were conducted in this study, for a 
quantitative assessment of the influence of the parameters current (A), welding speed (S), powder feed rate (F) and dilution. The levels of the factors used in the PTA-P and its factorial design codes are presented in Table 2 .

Table 2: Control parameters and their levels.

\begin{tabular}{l|c|c|r|r|r}
\hline \multirow{2}{*}{\multicolumn{1}{c|}{ PARAMETER }} & \multirow{2}{*}{ UNITS } & \multirow{2}{*}{ NOTATION } & \multicolumn{3}{|c}{ FACTOR LEVELS } \\
\cline { 4 - 7 } & \multicolumn{1}{c|}{ A } & I & 184 & \multicolumn{1}{c}{0} & \multicolumn{1}{c}{+1} \\
\hline Current & $\mathrm{m} / \mathrm{min}$ & $\mathrm{S}$ & 10 & 13 & 228 \\
\hline Welding speed & $\mathrm{g} / \mathrm{min}$ & $\mathrm{F}$ & 28 & 30 & 32 \\
\hline Powder feed rate & & & & & \\
\hline
\end{tabular}

\subsection{Dilution}

The dilution ratio is the percentage of the base metal that dissolves with the filler metal forming the chemical composition of the weld metal. For evaluation of the dilution (D\%), the samples were taken from the crosssection of each coated plate to obtain mean values and their respective variation for the D (\%), calculated as illustrated in Figure 2.

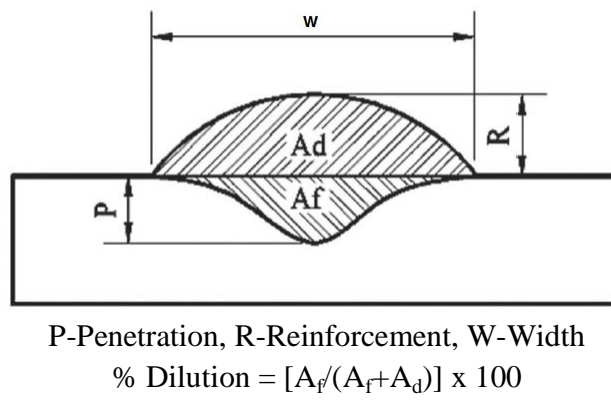

Figure 2: Weld bead geometry and illustration of D (\%) calculation.

\subsection{Microhardness}

The microhardness profile was determined by standard microhardness testing using a Future Tech FM-700 digital microhardnessmeter with a load of 100 grams-force (gf) for 15 seconds -the distance between the indenting was $200 \mu \mathrm{m}$ in WM, heat-affected zone (HAZ) and base metal (BM). Measurements of Vickers microhardness (HV) were carried out in each sample along three lines, as illustrated in Figure 3. This methodology was employed to meet the hardness gradient along the coating (WM) and substrate (HAZ and BM).

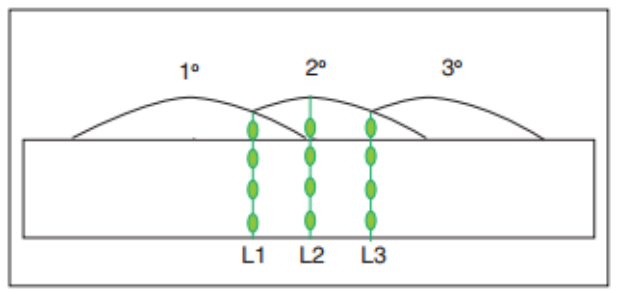

Figure 3: Provision of microhardness indents[1].

\subsection{Corrosion Analysis}

Before carrying out the analysis of electrochemical corrosion of coatings, the surface of the samples were machined for planing, getting with a fixed height of $3 \mathrm{~mm}$ as regulatory norm N-1707 of Petrobras for coating $[1,18]$. Electrochemical corrosion measurements were performed on a conventional three-electrode elec- 
trochemical cell. The working electrode was the steel sample API 5L X70 coated with Inconel alloy 625, the saturated calomel electrode was used as reference electrode and spiral shaped platinum wire as counter electrode. The linear potentiodynamic polarization (LPP) and electrochemical impedance spectroscopy (EIS) measurements were performed. The potentiostat/galvanostat Autolab PG STATE 30 connected to NOVA 1.9 software was used for electrochemical measurements. The EIS measurements were carried out at an interval of $1000 \mathrm{kHz}$ to $0.004 \mathrm{~Hz}$ frequency and an amplitude of $0.001 \mathrm{~V}$. All tests were conducted in the corrosive medium containing $60 \mathrm{ml}$ of $0.1 \mathrm{M} \mathrm{NaCl}$ at room temperature (around $25{ }^{\circ} \mathrm{C}$ ).

\section{RESULTS AND DISCUSSION}

\subsection{Effects of PTA-P process parameters on the dilution}

The values of the dilution $(\mathrm{D} \%)$, iron content $(\mathrm{Fe} \%)$, and heat input $(\mathrm{H})$, employed in coating application resulting from the PTA-P process are presented in Table 3. The D values ranged from 4.39 to $15.33 \%$, which are considered ideal for metal coatings applied by welding for applications such as hard coatings and corrosion resistant coatings. GATTO et al. [8], On the other hand, Petrobras adopts for pressure vessels with internal coating with dilution values in the range of $10 \%$.

Table 3: Dilution, iron content and welding energy employed in application of the coating resulting from the PTA-P process.

\begin{tabular}{l|c|c|c|r|r|r}
\hline EXPERIMENT & I(A) & $\mathbf{S}(\mathbf{c m} / \mathbf{m i n})$ & $\mathbf{F}(\mathbf{g} / \mathbf{m i n})$ & \multicolumn{1}{l|}{$\mathbf{D} \%$} & \multicolumn{1}{l|}{ Fe \% } & $\mathbf{H} \mathbf{( k J / c m})$ \\
\hline 1 & -1 & -1 & -1 & 5.65 & 3.96 & 12.86 \\
\hline 2 & 1 & -1 & -1 & 15.33 & 15.18 & 18.99 \\
\hline 3 & -1 & 1 & -1 & 5.02 & 3.60 & 8.34 \\
\hline 4 & 1 & 1 & -1 & 14.12 & 10.88 & 12.38 \\
\hline 5 & -1 & -1 & 1 & 5.06 & 6.62 & 12.48 \\
\hline 6 & 1 & -1 & 1 & 14.71 & 15.84 & 18.10 \\
\hline 7 & -1 & 1 & 1 & 4.39 & 1.43 & 7.61 \\
\hline 8 & 1 & 1 & 1 & 13.68 & 10.62 & 10.56 \\
\hline 10 & 0 & 0 & 0 & 10.59 & 6.94 & 13.38 \\
\hline 11 & 0 & 0 & 0 & 10.48 & 7.97 & 13.08 \\
\hline
\end{tabular}

The assessment results of the effects of the PTA-P process parameters on the dilution were obtained using the factorial matrix and response surface methodology (RSM), in which a linear model, Equation 1, was obtained that allowed to investigate the parameters and form of interaction between them.

$$
\% D=9.780-4.715 * I-0.442 * S-0.228 * F-0.117 * I * S-0.02 * I * F-0.0175 * S * F+0.0275 * I * S * F
$$

Where: $\mathrm{I}=$ welding current; $\mathrm{S}=$ welding speed; $\mathrm{F}=$ Powder feed rate and $\mathrm{I} * \mathrm{~S}, \mathrm{I} * \mathrm{~F}, \mathrm{~S} * \mathrm{~F}$ and $\mathrm{I} * \mathrm{~S} * \mathrm{~F}$ are the interactions of the parameters.

The response surface built for dilution is presented in Figure 4. It is observed that the minimum percentage of dilution $(4.8 \%)$ occurs at the current $184 \mathrm{~A}(-1)$, welding speed $16 \mathrm{~cm} / \mathrm{min}(+1)$ and powder feed rate fixed at $32 \mathrm{~g} / \mathrm{min}(+1)$. This value is close to the experimental value obtained in experiment 7 under the same conditions as for $4.39 \%$. 


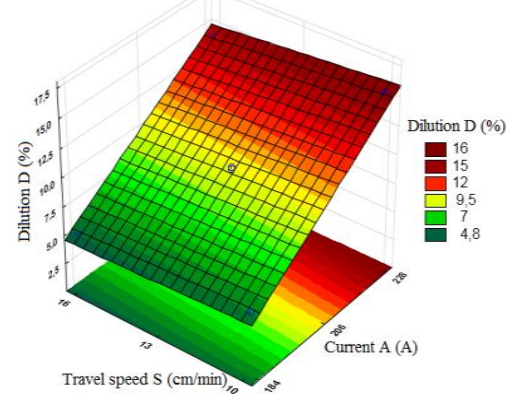

Figure 4: Response surface showing interaction effect of current (I) and welding speed (S) for dilution (\%) at constant powder feed rate $32 \mathrm{~g} / \mathrm{min}(+1)$.

The results presented in Figure 4 indicate that as the welding current is increased from 184 A (-1) to $228 \mathrm{~A}(+1)$, the dilution increases from 4.39 to $15.33 \%$, due the increase in $\mathrm{H}$, which promotes an increase in the heat of entry in the molten area of the weld pool.

It is evident from Figure 4 that with increase in the welding speed the dilution decreases, due to the shorter time of heat input in the weld pool and the decrease in the deposited powder. When the welding speed increased from $10 \mathrm{~cm} / \mathrm{min}(-1)$ to $16 \mathrm{~cm} / \mathrm{min}(+1)$, the heat input decreased from $18.99 \mathrm{~kJ} / \mathrm{cm}$ to $7.61 \mathrm{~kJ} / \mathrm{cm}$ respectively,. This is because the speed is inversely proportional to the $\mathrm{H}$, providing a lower amount of heat in the substrate, and promoting a greater reduction in the area of deposited metal [19].

It was observed that with the increase in feed rate the lowest dilution values were obtained. This behavior may be associated with the cooling of the plasma arc column which caused the heat to decrease in the area of the molten region [20].

The results of the analysis of variance (ANOVA), $\mathrm{F}$ test and determination coefficient $\left(\mathrm{R}^{2}\right)$ are presented in Table 4.

Table 4: Analysis of variance to evaluate the dilution (D\%).

\begin{tabular}{l|l|l|l|l}
\hline FACTOR & SS & DF & MS & F $_{\text {CALCULATED }}$ \\
\hline Regression & 180.1882 & 7 & 25.74 & 1532.21 \\
\hline Residue & 0.0504 & 3 & 0.01680 & - \\
\hline F. Adjust & 0.035933 & 1 & 0.03593 & - \\
\hline Pure Error & 0.0145 & 2 & 0.00723 & - \\
\hline Total & 180.2386 & 10 & - & - \\
\hline $\mathrm{R}^{2}$ & $99.7 \%$ & - & - & - \\
\hline $\mathrm{F}_{\text {tabulated }}$ & 8.89 & $\mathrm{~F}_{\text {calc }} / \mathrm{F}_{\text {tab }}=172,35$ & \\
\hline
\end{tabular}

The data in Table 4 indicate that the model obtained, Equation 1, possesses determination coefficient $\left(\mathrm{R}^{2}\right)$ equal to $99.7 \%$ of the variations obtained explained by the model; ratio of $\mathrm{F}_{\text {calculated }}$ and $\mathrm{F}_{\text {tabelated }}$ equal to 172.35 indicate that the model is statistically significant with $95 \%$ confidence due to the ratio being greater than one, and it is useful for predictive purposes as a result of being greater than four [21].

\subsection{Microhardness}

The microhardness profile of the cross section of weld metal (WM), heat-affected zone (HAZ) and base metal (BM) for the coatings of the experiments 2 and 3 are illustrated in Figures $5 \mathrm{a}$ and $5 \mathrm{~b} .18 .99 \mathrm{~kJ} / \mathrm{cm} \mathrm{H}$ value was applied in the experiment 2 , and $8.34 \mathrm{~kJ} / \mathrm{cm} \mathrm{H}$ value in experiment 3 . The The microhardness values are presented on the $\mathrm{Y}$-axis and the indents are on the $\mathrm{X}$-axis. It can be noted that the behavior of the microhardness profiles in both experiments are similar in regions of the WM and HAZ, showing a superior microhardness level in WM than in HAZ. In case of $\mathrm{H}=18.99 \mathrm{~kJ} / \mathrm{cm}$ the WM and HAZ average hardness values were $(259.44 \pm 4) \mathrm{HV}$ and $(243.41 \pm 5) \mathrm{HV}$ respectively. And for $\mathrm{H}=8.34 \mathrm{~kJ}$ it were $(272.0 \pm 7) \mathrm{HV}$ and $(261.37$ $\pm 8) \mathrm{HV}$, respectively. The results showed an average increase of 17.96 (HV) microhardness of HAZ when 
the $\mathrm{H}$ values were reduced from $18.99 \mathrm{KJ} / \mathrm{cm}$ to $8.34 \mathrm{~kJ} / \mathrm{cm}$. The lower heat input resulted in higher cooling rates and, consequently, in a higher microhardness value in HAZ. An increase of $20 \mathrm{HV}$ in a HAZ on reduction of welding energy from $15 \mathrm{~kJ} / \mathrm{cm}$ to $11 \mathrm{~kJ} / \mathrm{cm}$ are reported in the literature [22]. This fact can be explained in function of the cooling rate variation and, consequently, in the microhardness levels of HAZ.

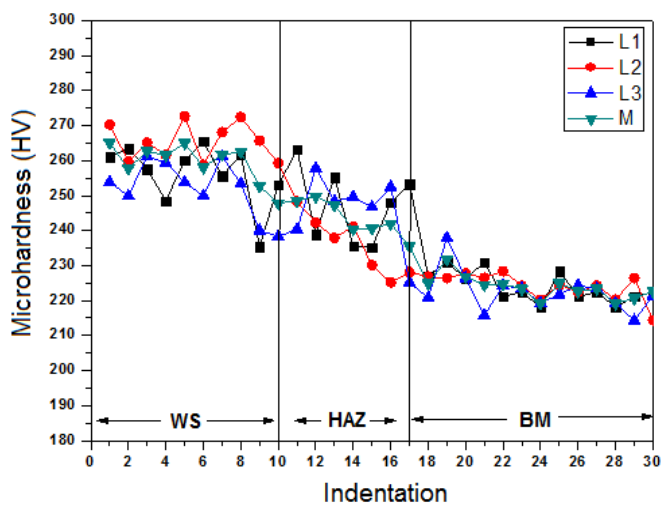

(a)

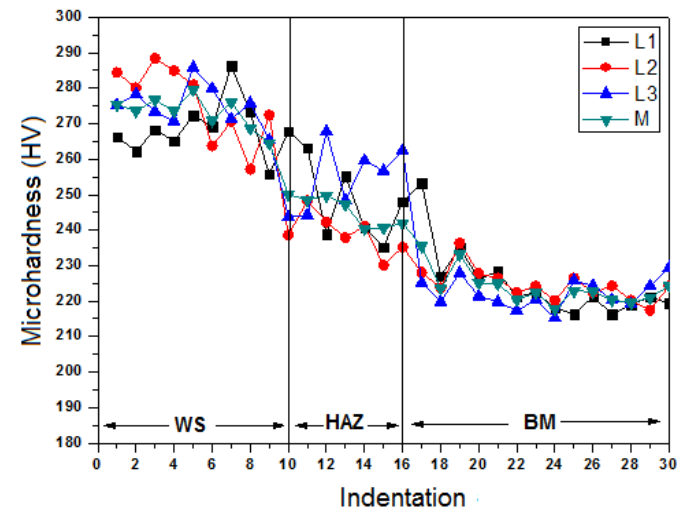

(b)

Figure 5: (a) Microhardness profile for $\mathrm{H}=18.99 \mathrm{~kJ} / \mathrm{cm}$ and (b) $\mathrm{H}=8.34 \mathrm{~kJ} / \mathrm{cm}$.

\subsection{Analysis of electrochemical corrosion}

The analysis of coatings electrochemical corrosion was conducted by linear potentiodynamic polarization (LPP), which is a standard method to evaluate corrosion resistance of materials in certain environments. It has the advantage of determining the corrosion rate by anodic or cathodic polarization of a few millivolts around the corrosion potential of metal or metal alloy [23,24]. The electrochemical impedance spectroscopy (EIS) technique was used for confirmation of the results of the LPP. The EIS is used to study the electrochemical behavior of materials and interfaces, which is widely used in the study of the corrosion phenomena [25].

The polarization curves of experiments 2 and 7 are illustrated in Figure 6, which had the highest and lowest level of dilution, $15.33 \%$ and $4.39 \%$ respectively, among the 11 experiments performed.

The experiment 2 with higher level of dilution and iron content presented corrosion potential ( $\mathrm{E}_{\mathrm{Corr}}$ ), $0.343 \mathrm{~V}$, that is, more positive than that of experiment $7,(-0.519 \mathrm{~V})$, with higher dilution and iron content. This result demonstrates that the experiment 7 has noncorrosive properties less than that of experiment 2 , as the potentiodynamic polarization results shown in Table 5.

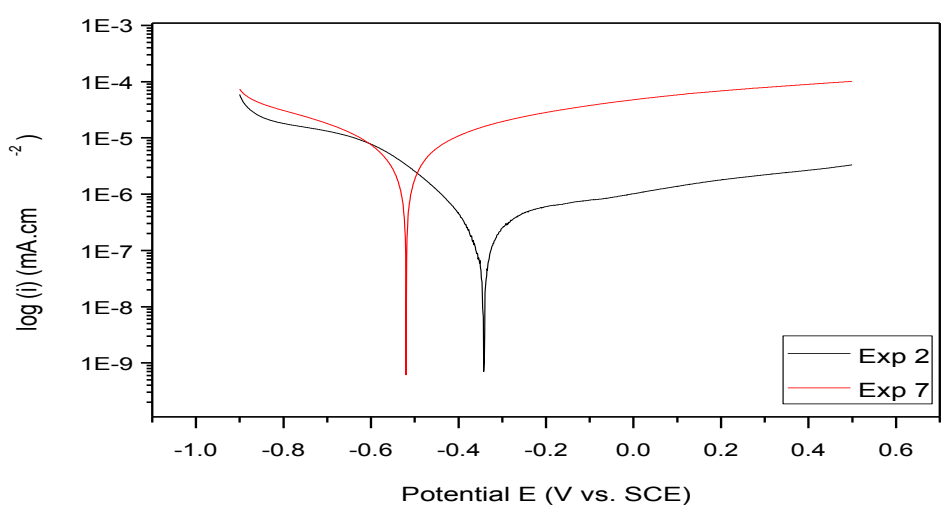

Figure 6: Polarization curves of experiments 2 and 7 obtained at atmospheric temperature $\left( \pm 25^{\circ} \mathrm{C}\right)$. 
Table 5: Results of the potentiodynamic polarization tests.

\begin{tabular}{l|l|l|l|l|l}
\hline EXPERIMENT & $\mathbf{J}_{\text {Corr }}\left(\boldsymbol{\mu A} / \mathbf{c m}^{2}\right)$ & $\begin{array}{l}\mathbf{I}_{\text {corr }} \\
(\boldsymbol{\mu A})\end{array}$ & $\begin{array}{l}\text { CORROSION RATE } \\
(\mathbf{m m} / \text { year) }\end{array}$ & $\begin{array}{l}\mathbf{R}_{\mathbf{p}} \\
\left(\mathbf{K} \mathbf{\Omega} . \mathbf{c m}^{2}\right)\end{array}$ & $\begin{array}{l}\mathbf{E}_{\text {Corr }} \\
(\mathbf{V})\end{array}$ \\
\hline 2 & 141.61 & 141.61 & 0.0016 & 169.76 & -0.343 \\
\hline 7 & 4.667 & 4.667 & 0.054 & 10.95 & -0.519 \\
\hline
\end{tabular}

*Corrosion current density (Jcorr), corrosion current (Icorr), polarization resistance (Rp) and corrosion potential (Ecorr).

For confirmation of the results of LPP curves on the corrosion resistance, EIS measurements were done Electrochemical impedance spectroscopy is a technique used to study the electrochemical behavior of materials and interfaces, which is widely used in the study of corrosion [26]. According to Macdonald and Sun [27], impedance electrochemistry is used to evaluate the corrosion resistance of metals and alloys, as well as to characterize the oxide layers.

The Nyquist diagrams of coatings with Inconel 625 of experiments 2 and 7 that were evaluated by LPP are presented in Figure 7 (a) and (b), which had the highest and lowest level of dilution, 15.33\% and $4.39 \%$, respectively.

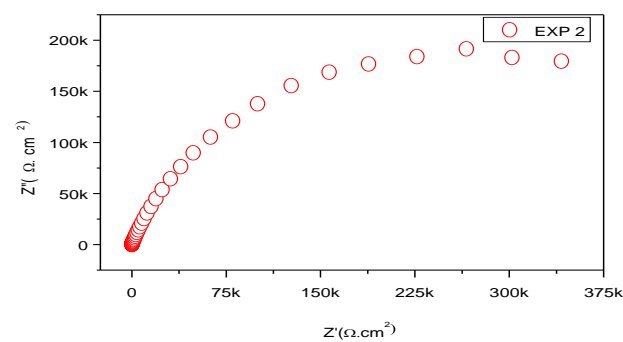

(a)

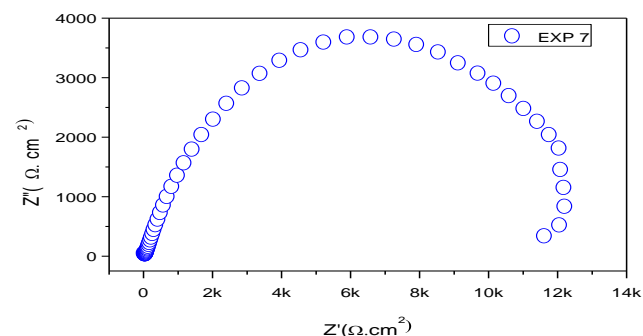

(b)

Figure 7: Nyquist diagrams of: (a) experiments 2, and (b) experiment 7 obtained versus SCE at atmospheric temperature $\left( \pm 25^{\circ} \mathrm{C}\right)$

According to the results shown in Figure 7 (a), the experiment 2 presented higher results of impedance, showing the largest semicircle formed with the real axis. This indicates that the sample was more passive due to increased difficulty of conducting current, that is, the rate of corrosion is less when compared with the experimental sample 7. Therefore, these results confirm the values found by LPP, which indicated that the experiment with higher level of dilution and higher iron content presented a greater polarization resistance.

According to Souza et al, [28] this increased corrosion resistance in coatings applied with greaterheat input, despite the higher dilution and consequently higher iron content on the surface, should be due to lower cooling speed and hence favoring proper chemical balance between the phases, that outperformes the high iron content on the surface. The explanation may also be related to the level of compressive residual stresses, that is, the higher theheat input, greater will be the level of compressive residual stresses, consequently greater the corrosion resistance. Similar result was obtained by Melo [29], who obtained the deposition by submerged arc welding (SAW) process, an increase of $41 \mathrm{MPa}$ in compressive residual stress by increasing the $12.90 \mathrm{~kJ} / \mathrm{cm}$ welding energy to $14 \mathrm{~kJ} / \mathrm{cm}$, resulting in a polarization resistance of $194 \mathrm{k} \Omega . \mathrm{cm}^{2}(12.90$ $\mathrm{kJ} / \mathrm{cm})$ and $206 \mathrm{k} \Omega \cdot \mathrm{cm}^{2}(14 \mathrm{~kJ} / \mathrm{cm})$.

\section{CONCLUSIONS}

Based on the study of this work, the following conclusions can be drawn:

The PTA-P welding process obtained coatings ranging from $4.39 \%$ to $15.33 \%$ dilution values

It was observed that the best dilution values were obtained with $184 \mathrm{~A}$ welding current, $16 \mathrm{~cm} / \mathrm{min}$ welding speed and $32 \mathrm{~g} / \mathrm{min}$ feed rate for getting a value of $4.39 \%$ dilution. 
An average increase of $17.96(\mathrm{HV})$ microhardness of HAZ occurred on reducing the welding energy from $\mathrm{H}=18.99 \mathrm{~kJ} / \mathrm{cm}$ to $8.34 \mathrm{~kJ} / \mathrm{cm}$.

The best result of corrosion potential observed was $-0.343 \mathrm{~V}$ for the sample of experiment 2 (228 A, 10 $\mathrm{m} / \mathrm{min}$ and $28 \mathrm{~g} / \mathrm{min}$ )

The best values of corrosion potential and polarization resistance were obtained with the higher dilution and iron content.

\section{ACKNOWLEDGMENTS}

The Capes / CNPq programs for financial support through the Research Grants.

\section{BIBLIOGRAPHY}

[1] SANTOS, A. X. T., MACIEL, M., SANTANA, R. A. C., "Avaliação de revestimentos à base de Inconel 625 depositados através do processo de soldagem GMAW em aço API 5L X70 utilizando planejamento fatorial”, Revista Brasileira de Aplicações a Vácuo, v. 34, n. 3, pp. 128-140, Dez. 2015.

[2] BEIDOKHTI, B., DOLATI, A., KOUKABI, A. H. "Effects of alloying elements and microstructure on the susceptibility of the welded HSLA steel to hydrogen-induced cracking and sulfide stress cracking", Materials Science and Engineering A, v.507, n. 1-2, pp. 167-173, May. 2009.

[3] ALIZADEH, M., BORDBAR, S. "The influence of microstructure on the protective properties of the corrosion product layer generated on the welded API X70 steel in chloride solution", Corrosion Science, v.70, pp. 170-179, May. 2013.

[4] ANTUNES, R. A., MACHADO, C. A. V. A., CORREA, O. V. "Influence of testing temperature on the corrosion behavior of API 5L X70 pipeline", In: 22nd International Congress of Mechanical Engineering (COBEM), pp. 3252-3256, Ribeirão Preto, Nov. 2013.

[5] LIANG, Z., XIAOGANG, L., CUIWEI, D., et al., "Effect of applied potentials on stress corrosion cracking of X70 pipeline steel in alkali solution”, Materials and Design, v.30, n. 6, pp. 2259-2263, Jun. 2009.

[6] OSKUIE, A. A., SHAHRABI, T., SHAHRIARI, A., SAEBNOORI, E. "Electrochemical impedance spectroscopy analysis of X70 pipeline steel stress corrosion cracking in high $\mathrm{pH}$ carbonate solution", Corrosion Science, v. 61, pp. 111-122, Aug. 2012.

[7] DAVIS, J. R., "Hardfacing, weld cladding, and dissimilar metal joining." In: ASM International, v.6, ASM Handbook, pp. 789-829, 1993.

[8] GATTO, A., BASSOLI, E., FORNARI, M. "Plasma Transferred Arc deposition of powdered high performances alloys: process parameters optimisation as a function of alloy and geometrical configuration", Surface and Coatings Technology, v. 187, n. 2-3, pp. 265-271, Oct. 2004.

[9] ZHANG, L., SUN, D., YU, H. "Effect of niobium on the microstructure and wear resistance of iron-based alloy coating produced by plasma cladding", Materials Science and Engineering A, v.490, n. 1-2, pp. 57-61, Aug. 2008.

[10] LIU, Y. F., MU, J. S., XU, X. Y., et al., "Microstructure and dry-sliding wear properties of TiCreinforced composite coating prepared by plasma-transferred arc weld-surfacing process", Materials Science and Engineering A, v.458, n. 1-2, pp. 366-370, Jun. 2007.

[11] SILVA, R. H. G. E., DUTRA, J. C. "Processo PTA-P - Uma Revisão da Literatura como Base para Inovações. Parte 2 de 2: Comportamento Térmico e Cinemático do Pó, Parâmetros e Consumíveis do Processo", Soldagem e Inspeção, v. 17, n. 2, pp. 173-183, Abr/Jun. 2012.

[12] LIM, L. C., MING, Q., CHEN, Z. D. "Microstructures of laser-clad nickel-based hardfacing alloys", Surface \& Coatings Technology, v. 106, pp. 183-192, 1998.

[13] AL-FADHLI, H. Y., STOKES, J., HASHMI, M. S. J., et al., "The erosion-corrosion behaviour of high velocity oxy-fuel (HVOF) thermally sprayed inconel-625 coatings on different metallic surfaces", Surface and Coatings Technology, v. 200, n. 20-21, pp. 5782-5788, May. 2006.

[14] CORREIA, D. S., GONÇALVES, C. V., CUNHA, S. S., et al., "Comparison between genetic algorithms and response surface methodology in GMAW welding optimization", Journal of Materials Processing Technology, v. 160, n. 1, pp. 70-76, Mar. 2005. 
[15] OLIVEIRA, A. L. M., COSTA, J. D., SOUSA, M. B., et al., "Studies on electrodeposition and characterization of the Ni-W-Fe alloys coatings", Journal of Alloys and Compounds, v. 619, pp. 697-703, Jan. 2015.

[16] SANTANA, R. A. C., PRASAD, S., MOURA, E. S., et al., "Studies on electrodeposition of corrosion resistant Ni-Fe-Mo alloy", Journal of Materials Science, v. 42, n. 7, pp. 2290-2296, Apr. 2007.

[17] COSTA, J. D., SOUSA, M. B., LIA FOOK, N. C. M., et al., "Obtaining and characterization of NiTi/Ti-Mo joints welded by TIG process", Vacuum, v. 133, pp. 58-69, Nov. 2016.

[18] BILÓ, T. C., SILVEIRA, I. C. A., BELO, W. C., et al., "Methods for estimating the velocities of the Brazil Current in the pre-salt reservoir area off southeast Brazil (23॰S-26 ${ }^{\circ}$ S)", Ocean Dynamics, v. 64. n. 10, pp. 1431-1446, Oct. 2014.

[19] PESSOA, A. R. P., MIRANDA, H. C., FARIAS, J. P., et al., "Seleção de parâmetros através do método Taguchi para soldagem de revestimento com ligas de níquel pelo processo MIG/MAG", Soldagem e Inspeção, v. 15, n. 4, pp. 317-324, Out/Dez. 2010.

[20] DEUIS, R. L., YELLUP, J. M., SUBRAMANIAN, C. "Metal-matrix composite coatings by PTA surfacing”, Composites Science and Technology, v.58, n. 2, pp. 299-309, 1998.

[21] BARROS NETO, B., SCARMINIO, I. S., BRUNS, R. E. Planejamento e Otimização de Experimentos, 2. Ed., São Paulo, Editora Unicamp, 2005.

[22] KEJELIN, N. Z., BUSCHINELLI, A. J. A., BOHÓRQUEZ, C. E. N. "Soldagem Dissimilar do Aço X60 com Inconel 625", http://www.labsolda.ufsc.br/noticias/2007/soldagem_dissimilar.pdf. Accessed July 2017.

[23] LEE, C. R., KANG, S. G. "Electrochemical stability of Co-Mo intermetallic compound electrodes for hydrogen oxidation reaction in hot KOH solution", Journal of Power Sources, v. 87, n. 1-2, pp. 64-68, Apr. 2000.

[24] LIU, C., LIN, G., YANG, D., et al., "In vitro corrosion behavior of multilayered Ti/TiN coating on biomedical AISI 316L stainless steel", Surface and Coatings Technology, v. 200, n. 12-13, pp. 4011-4016, Mar. 2006.

[25] CHANG, L. M., WANG, Z. T., SHI, S. Y., et al., "Study on microstructure and properties of electrodeposited Ni-W alloy coating with glycolic acid system", Journal of Alloys and Compounds, v. 509, n. 5, pp. 1501-1504, Feb. 2011.

[26] HAERI, M., GOLDBERG, S., GILBERT, J. L. "The voltage-dependent electrochemical impedance spectroscopy of CoCrMo medical alloy using time-domain techniques: Generalized Cauchy-Lorentz, and KWW-Randles functions describing non-ideal interfacial behavior", Corrosion Science, v. 53, n. 2, pp. 582588, Feb. 2011.

[27] MACDONALD, D. D., SUN, A. "An electrochemical impedance spectroscopic study of the passive state on Alloy-22", Electrochimica Acta, v. 51, n. 8-9, pp. 1767-1779, Jan. 2006.

[28] SOUZA, C. S., LINS, V. F. C., SILVEIRA, D. M., et al., "Avaliação da Soldagem Multipasse de Chapas Espessas de Aços Inoxidáveis Lean Duplex UNS S32304 Soldadas pelos Processos SMAW, GMAW e FCAW - Parte II: Resistência à Corrosão", Soldagem e Inspeção, v. 18, n. 3, pp. 257-267, Jul/Set. 2013.

[29] MELO, R. H. F., Avaliação da influência do processo e dos parâmetros de soldagem sobre a resistência à corrosão de revestimentos de aço inoxidáveis AWS e 308-L T1 aplicados em aços ASTM A36, Dissertação de M. Sc., UFCG, Campina Grande, PB, Brazil, 2013.

\section{ORCID}

Aureliano Xavier dos Santos

Theophilo Moura Maciel

Josiane Dantas Costa

Mikarla Baía de Sousa

Shiva Prasad

Ana Regina Nascimento Campos

Renato Alexandre Costa de Santana https://orcid.org/0000-0002-6370-6575

https://orcid.org/0000-0002-2539-3336

https://orcid.org/0000-0001-9835-8016

https://orcid.org/0000-0001-7478-5312

https://orcid.org/0000-0003-4526-7545

https://orcid.org/0000-0001-9029-6922

https://orcid.org/0000-0002-7075-7709 